(C) 1983. The Genetical Society of Great Britain

\title{
DISTRIBUTION AND HERITABILITY OF THE RED RAYLETS IN Heliconius erato phyllis (LEPID.; NYMPH.)
}

\author{
MARIA C. G. PANSERA AND ALDO M. ARAÚJO* \\ Departamento de Biologia, FIDENE, ljui, RS, Brasil \\ * Departamento de Genética, UfRGS C. Postal 1953 90.000-Porto Alegre, RS, Brasil
}

Received 5.11.82

\section{SUMMARY}

\begin{abstract}
The present report deals with the description of the distribution of the red raylets in populations of Heliconius erato phyllis living in the South of Brazil (Parque Florestal Estadual do Turvo, State of Rio Grande do Sul). This was done during a period of one and a half years. Great variability was observed in the distributions of sub-populations along two little roads inside the forest. Nevertheless, in only two comparisons significant results were obtained. Estimates of heritabilility of the red raylets were done by the methods of regression and analysis of variance: the former was 0.74 and the latter, 1.09 ; the reasons for such discrepancy are discussed. A consideration of marginal and central populations is brought about by the comparison of this study with a previous one made in a different locality of the State of Rio Grande do Sul.
\end{abstract}

\section{INTRODUCTION}

The evolutionary importance of quantitative characters in natural populations due to their rapid response to ecological conditions, was stressed by Ford (1975). As ecological genetics aims to study the adaptation of populations to their environment such characters would be very useful, since the variability could be detected and analysed with living organisms. As far as lepidoptera populations are concerned, few studies were done, the exception being the satyrid Maniola jurtina. From the pioneering work of Dowdeswell et al., (1949), up to Brakefield (1979; see also 1982a,b), the number of spots in the hindwings were studied regarding their distribution, genetics, and evolution in island and continental populations. Species phylogenetically related to jurtina were also studied by Frazer and Willcox (1979).

As for tropical butterflies, Owen (1971) dealt with the genus Acraea in Africa and the distribution of a series of spots in both wings. In the Neotropics, the genus Heliconius has received great attention by several workers (see reviews in Brown, 1981 and Turner, 1981). Variation in a quantitative trait was first noticed by Emsley (1964) in the East Brazil race $H$. erato phyllis: small red raylets, which can vary from 1 to 6 , occasionally 7 , below the hindwing yellow bar (fig. 1) mainly visible on the ventral surface (Saalfeld and Araújo, 1981). The genetics of the colour patterns was studied by Sheppard et al., (in press); however, in regard to the inheritance of the red raylets they refer: "We have not studied these in detail. ... It may be that this is a single, recessive allele, polymorphic in the East Brazilian subspecies" (pp. 155, manuscript). Saalfeld and Araújo (1981) reported a bimodal distribution for the red raylets in a natural population (modes in 3 and 5 raylets) inhabiting a marginal environment near Porto Alegre, Rio Grande do Sul. This finding stimulated us to proceed investigating the trait to answer the following questions: (i) is the trait under genetic control? 
a)



b)

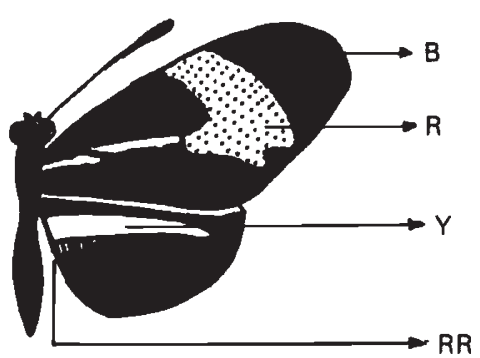

FIG. 1(a) Geographical situation of the Parque Florestal Estadual do Turvo (PFET) in the State of Rio Grande do Sul, Brazil. (b) General pattern of $H$. $e$. phyllis, the East Brazil race. $B=$ black; $R=$ red; $R R=$ red raylets (visible mainly on the underside of the hindwings); $\mathrm{Y}=$ yellow.

Is it simple or polygenic? (ii) What is the shape of the distributions in a central environment? The present work describes the variability found in a central population of Heliconius erato phyllis as well as estimates of the heritability of the red raylets by the methods of regression and analysis of variance.

\section{MAterials AND METHOdS}

A total of 1167 imagos were studied in nature by the capture-recapture method and 325 were reared in an insectary. All field work was done in the Parque Florestal Estadual do Turvo (PFET) by means of visits made there each three months, from July 1979 until February 1981. PFET is a nature reserve distant about $500 \mathrm{~km}$ from Porto Alegre, Rio Grande do Sul (fig. 
1); it has co-ordinates $27^{\circ}-27^{\circ} 20^{\prime} \mathrm{S}$ and $53^{\circ} 40^{\prime}-54^{\circ} 10^{\prime} \mathrm{W}$. Its northern geographical limits are Republica Argentina and the Brazilian State of Santa Catarina through river Uruguai over a distance of $45 \mathrm{~km}$ (Plano de Manejo do PFET, 1980). The climate is subtropical temperate and the region is considered to represent a "hot winter" (the minimum mean is $11^{\circ} \mathrm{C}$ and the maximum mean $23^{\circ} \mathrm{C}$, from June to August) (Buriol et al., 1979). The vegetation is of the type Continental Subtropical (Irgang, 1980).

Two roads have been studied: the first one $(A)$, inside the forest with $9 \mathrm{~km}$, having sub-populations of $H$. erato concentrated in kilometers 2,3 , $4,6,7.5$ and 9 . The second one (B), also inside the forest with $16 \mathrm{~km}$, having sub-populations in the kilometers $4 \cdot 5,6,13$ and 16 (this road, being longer than $\mathrm{A}$ was not sampled in its total extension, instead, some places were selected). The butterflies were captured using conventional nets, marked, scored for the red raylets and released.

In the insectary we got a total of 20 crosses, but only 9 could be used in the analysis since the remaining 11 showed a small number of descendants (less than 14) mainly due to the premature death of the ovipositing female (fig. 2). Each female was put to lay eggs in chambers containing the host

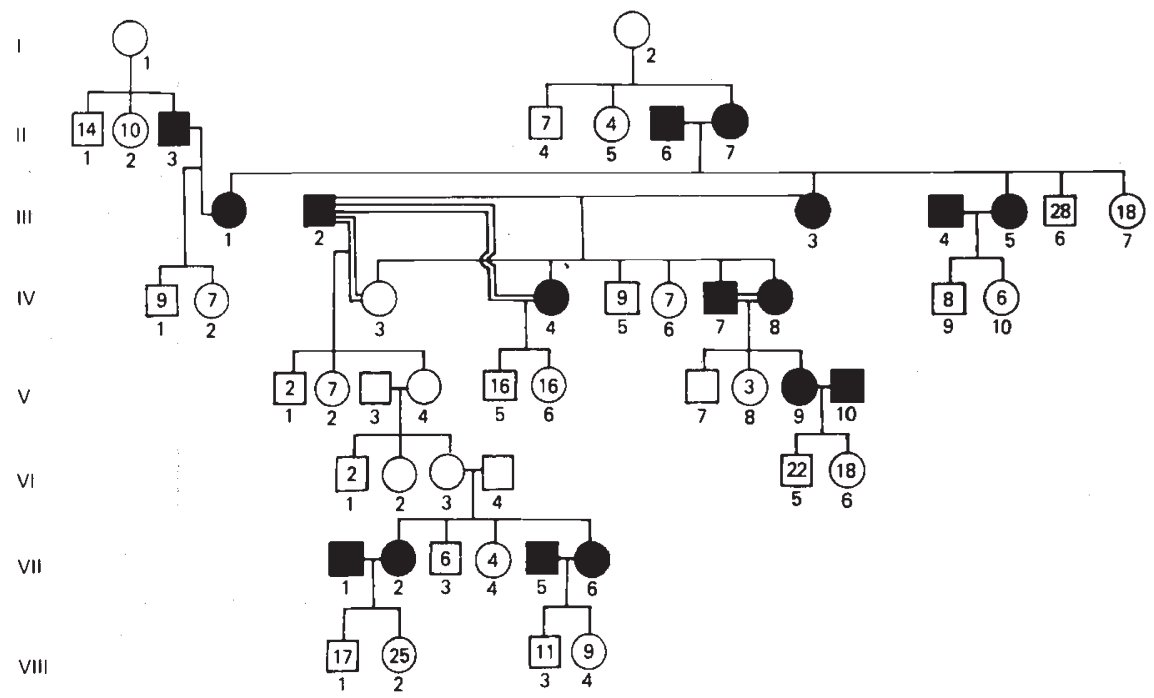

FIG. 2 Pedigree showing the nine crosses used in the present study (closed symbols). Numbers inside each symbol indicate the total of individuals of that sex.

plant and flowers for the adults as well as plants to make the environment suitable to the butterflies; food was supplemented sometimes by a mixture of honey and water $(1: 9)$. Four chambers were available, two of them measuring $3.20 \mathrm{~m} \times 2.40 \mathrm{~m} \times 2.80 \mathrm{~m}$ and the other two $3.50 \mathrm{~m} \times 2.00 \mathrm{~m} \times$ $2.00 \mathrm{~m}$; in none was there control of temperature. Eggs were collected daily and transferred individually to plastic vials since caterpillars are cannibalistic. Selected emerged adults were used in the crosses, especially those with contrasting numbers of raylets.

The estimates of heritability $\left(h^{2}\right)$ were done using two methods: the first is based on a linear regression of the number of red raylets in the 
offspring in relation to their parents. As greater accuracy in the calculation of $h^{2}$ could be obtained if separate regressions were made considering the combinations mother-offspring, father-offspring and parents-offspring, three coefficients of regression were used, each being calculated by considering the averages of the number of raylets in the above combinations. So, if $\bar{G}$ is the average of the number of raylets in both parents, $\bar{F}$ the average in the offspring, $P$, the actual number in the father and $M$, the actual number in the mother, the heritability can be expressed as a weighted mean (Beiguelman, 1977):

$$
h^{2}=\frac{2 b(\bar{F} P) \cdot I(\bar{F} P)+2 b(\bar{F} M) \cdot I(\bar{F} M)+b(\bar{F} \bar{G}) \cdot I(\bar{F} \bar{G})}{I(\bar{F} P)+I(\bar{F} M)+I(\bar{F} \bar{G})}
$$

where $I$ is the inverse of the respective coefficient of regression (invariance). The second method utilises the analysis of variance, the value of $h^{2}$ being calculated after the procedure adopted by McWhirter (1969). As this method assumes the absence of inbreeding, two crosses were excluded from the analysis.

\section{Results}

\section{(i) Distribution of the red raylets}

Table 1 shows the distribution of the red raylets in butterflies captured along road A and table 2 along road B, from July 1979 to February 1981 as well as the sample size, mean and standard deviation of the trait. The

TABLE 1

Frequency distributions, sample size $(N)$, mean $(\bar{X})$ and standard deviation (S.D.) of the number of red raylets in butterflies captured along road $A$

\begin{tabular}{|c|c|c|c|c|c|c|c|c|c|c|}
\hline \multirow[b]{2}{*}{ Month/Year } & \multirow[b]{2}{*}{ Locality } & \multicolumn{7}{|c|}{ No. of Red raylets } & \multirow[b]{2}{*}{$N$} & \multirow[b]{2}{*}{$\bar{X} \pm$ S.D } \\
\hline & & 1 & 2 & 3 & 4 & 5 & 6 & 7 & & \\
\hline $\mathrm{Jul} / 79$ & $\mathrm{~km} 3$ & 2 & 4 & 20 & 5 & 10 & 3 & 0 & 44 & $3 \cdot 6 \pm 1 \cdot 3$ \\
\hline Oct $/ 79$ & $\begin{array}{l}\mathrm{km} 4 \\
\mathrm{~km} 6\end{array}$ & $\begin{array}{l}1 \\
2\end{array}$ & $\begin{array}{l}1 \\
1\end{array}$ & $\begin{array}{l}6 \\
1\end{array}$ & $\begin{array}{l}3 \\
3\end{array}$ & $\begin{array}{l}0 \\
4\end{array}$ & $\begin{array}{l}0 \\
1\end{array}$ & $\begin{array}{l}0 \\
0\end{array}$ & $\begin{array}{l}11 \\
12\end{array}$ & $\begin{array}{l}3.0 \pm 0.9 \\
3.8 \pm 1.7\end{array}$ \\
\hline $\operatorname{Jan} / 80$ & $\begin{array}{l}\mathrm{km} 2 \\
\mathrm{~km} 4 \\
\mathrm{~km} 7\end{array}$ & $\begin{array}{l}0 \\
1 \\
1\end{array}$ & $\begin{array}{l}5 \\
5 \\
0\end{array}$ & $\begin{array}{l}8 \\
2 \\
2\end{array}$ & $\begin{array}{r}16 \\
8 \\
0\end{array}$ & $\begin{array}{r}13 \\
13 \\
9\end{array}$ & $\begin{array}{r}9 \\
14 \\
4\end{array}$ & $\begin{array}{l}1 \\
1 \\
0\end{array}$ & $\begin{array}{l}52 \\
44 \\
16\end{array}$ & $\begin{array}{l}4 \cdot 3 \pm 1 \cdot 3 \\
4 \cdot 7 \pm 1 \cdot 4 \\
4 \cdot 8 \pm 1 \cdot 3\end{array}$ \\
\hline Apr $/ 80$ & $\begin{array}{l}\mathrm{km} 2 \\
\mathrm{~km} \mathrm{4} \\
\mathrm{km} 6 \\
\mathrm{~km} 7 \\
\mathrm{~km} 9\end{array}$ & $\begin{array}{l}0 \\
2 \\
1 \\
0 \\
1\end{array}$ & $\begin{array}{l}1 \\
1 \\
1 \\
1 \\
0\end{array}$ & $\begin{array}{l}5 \\
7 \\
4 \\
4 \\
3\end{array}$ & $\begin{array}{l}2 \\
6 \\
6 \\
9 \\
5\end{array}$ & $\begin{array}{r}5 \\
10 \\
25 \\
14 \\
6\end{array}$ & $\begin{array}{r}6 \\
9 \\
11 \\
11 \\
3\end{array}$ & $\begin{array}{l}0 \\
0 \\
0 \\
0 \\
0\end{array}$ & $\begin{array}{l}19 \\
35 \\
48 \\
39 \\
18\end{array}$ & $\begin{array}{l}4 \cdot 5 \pm 1 \cdot 4 \\
4 \cdot 4 \pm 1 \cdot 4 \\
4 \cdot 8 \pm 1 \cdot 1 \\
4 \cdot 8 \pm 1 \cdot 1 \\
4 \cdot 3 \pm 1 \cdot 3\end{array}$ \\
\hline $\mathrm{Jul} / 80$ & $\begin{array}{l}\mathrm{km} 2 \\
\mathrm{~km} 6 \\
\mathrm{~km} 7\end{array}$ & $\begin{array}{l}0 \\
2 \\
2\end{array}$ & $\begin{array}{l}2 \\
0 \\
2\end{array}$ & $\begin{array}{r}3 \\
10 \\
15\end{array}$ & $\begin{array}{l}3 \\
4 \\
9\end{array}$ & $\begin{array}{l}11 \\
10 \\
22\end{array}$ & $\begin{array}{l}2 \\
6 \\
9\end{array}$ & $\begin{array}{l}0 \\
0 \\
0\end{array}$ & $\begin{array}{l}21 \\
32 \\
59\end{array}$ & $\begin{array}{l}4 \cdot 4 \pm 1 \cdot 2 \\
4 \cdot 2 \pm 1 \cdot 4 \\
4 \cdot 2 \pm 1 \cdot 3\end{array}$ \\
\hline Oct $/ 80$ & km 6 & 2 & 1 & 5 & 4 & 3 & 3 & 0 & 18 & $3 \cdot 8 \pm 1 \cdot 6$ \\
\hline Feb/81 & $\begin{array}{l}\mathrm{km} 4 \\
\mathrm{~km} 4 \\
\mathrm{~km} 6\end{array}$ & $\begin{array}{l}4 \\
1 \\
0\end{array}$ & $\begin{array}{l}6 \\
1 \\
3\end{array}$ & $\begin{array}{r}12 \\
5 \\
9\end{array}$ & $\begin{array}{r}13 \\
7 \\
8\end{array}$ & $\begin{array}{r}13 \\
11 \\
7\end{array}$ & $\begin{array}{l}8 \\
8 \\
5\end{array}$ & $\begin{array}{l}0 \\
0 \\
0\end{array}$ & $\begin{array}{l}56 \\
33 \\
32\end{array}$ & $\begin{array}{l}3 \cdot 9 \pm 1 \cdot 4 \\
4 \cdot 5 \pm 1 \cdot 3 \\
4 \cdot 1 \pm 1 \cdot 2\end{array}$ \\
\hline
\end{tabular}



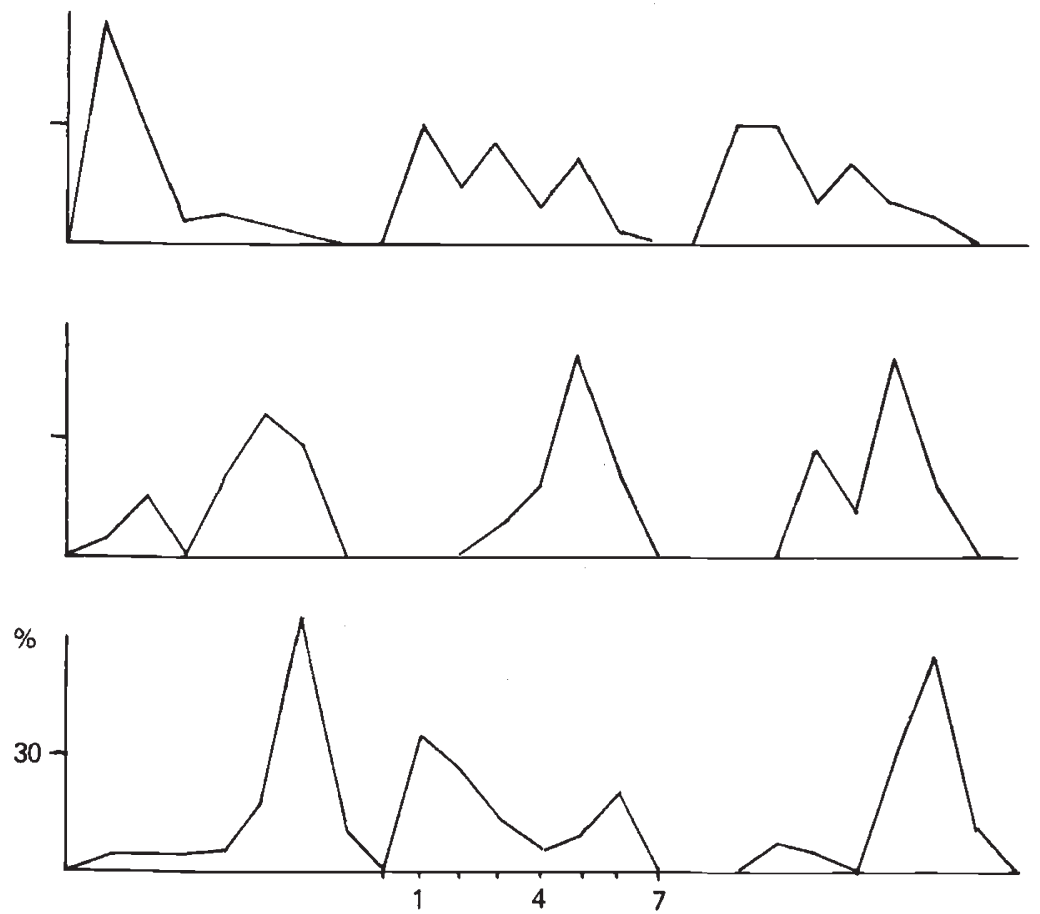

Fig. 3. Frequency polygons of the red raylets in the offspring of the nine crosses obtained in the insectary

TABLE 3

Distribution of the red raylets in the offspring of nine matings obtained in the insectary

\begin{tabular}{|c|c|c|c|c|c|c|c|c|c|c|c|}
\hline \multicolumn{3}{|c|}{ No. of raylets in } & \multicolumn{8}{|c|}{ Offspring } & \multirow{2}{*}{$\begin{array}{l}\text { Mean and } \\
\text { standard } \\
\text { deviation } \\
\text { of the } \\
\text { offspring }\end{array}$} \\
\hline $\begin{array}{c}\text { Cross } \\
\text { no. }\end{array}$ & $\begin{array}{c}8 \times \\
9\end{array}$ & $\begin{array}{c}\text { Parents' } \\
\text { mean }\end{array}$ & 1 & 2 & 3 & 4 & 5 & 6 & 7 & $N$ & \\
\hline I & $4-1$ & $2 \cdot 5$ & 27 & 14 & 2 & 3 & 2 & 1 & 0 & 49 & $1 \cdot 8 \pm 1 \cdot 2$ \\
\hline II & $5-1$ & $3 \cdot 0$ & 7 & 3 & 6 & 2 & 5 & 1 & 0 & 24 & $2.9 \pm 1.6$ \\
\hline III & $5-1$ & $3 \cdot 0$ & 6 & 6 & 2 & 4 & 2 & 1 & 0 & 21 & $2 \cdot 7 \pm 1 \cdot 6$ \\
\hline IV & $6-1$ & $3 \cdot 5$ & 1 & 4 & 0 & 5 & 9 & 7 & 0 & 26 & $4 \cdot 5 \pm 1 \cdot 5$ \\
\hline V & $1-7$ & $4 \cdot 0$ & 0 & 0 & 3 & 7 & 21 & 11 & 0 & 42 & $5 \cdot 0 \pm 0 \cdot 8$ \\
\hline VI & $3-6$ & $4 \cdot 5$ & 0 & 0 & 5 & 2 & 10 & 3 & 0 & 20 & $4 \cdot 6 \pm 1 \cdot 0$ \\
\hline VII & $5-4$ & $4 \cdot 5$ & 1 & 1 & 1 & 2 & 6 & 25 & 4 & 40 & $5 \cdot 6 \pm 1 \cdot 2$ \\
\hline VIII & $5-5$ & $5 \cdot 0$ & 9 & 6 & 3 & 1 & 2 & 5 & 0 & 26 & $2 \cdot 8 \pm 2 \cdot 0$ \\
\hline IX & $6-6$ & $6 \cdot 0$ & 0 & 2 & 1 & 0 & 8 & 18 & 3 & 32 & $5 \cdot 5 \pm 1 \cdot 2$ \\
\hline
\end{tabular}

a proportion of 65 to 91 per cent descendants with high number of raylets, the exception being cross VIII whose parents are brother and sister.

To test the equality of means in the offspring of the crosses an analysis of variance was performed, excluding crosses VIII and IX due to consanguinity of parents (table 4). A highly significant difference was obtained between crosses; a greater decomposition of the mean square between showed that only crosses IV and V had equal means. 
TABLE 4

Analysis of variance of the number of red raylets in the offspring of seven matings obtained in insectary (crosses VIII and IX were excluded due to consanguinity-see fig. 2)

\begin{tabular}{lrrrr}
\hline Source of variation & \multicolumn{1}{c}{$S S$} & \multicolumn{1}{c}{ df } & \multicolumn{1}{c}{$M S$} & \multicolumn{1}{c}{$F$} \\
\hline Between & $439 \cdot 0990$ & 6 & $73 \cdot 1832$ & $44 \cdot 8179^{* * *}$ \\
$\quad$ I; II; III; IV) $\times$ V & $149 \cdot 7640$ & 1 & $149 \cdot 7640$ & $91 \cdot 7166^{* * *}$ \\
I $\times$ II $\times$ III $\times$ IV & $119 \cdot 6832$ & 3 & $39 \cdot 8944$ & $24 \cdot 4316^{* * *}$ \\
IV $\times$ V & $3 \cdot 8689$ & 1 & 3.8689 & $2 \cdot 3693 \mathrm{NS}$ \\
VI $\times$ VII & $13 \cdot 3333$ & 1 & $13 \cdot 3333$ & $8 \cdot 1654^{* * *}$ \\
Within & $351 \cdot 0632$ & 215 & $1 \cdot 6329$ & \\
Total & $790 \cdot 1622$ & 221 & & \\
\hline
\end{tabular}

$* * *=P<0.001$.

$\mathrm{NS}=$ not significant.

The heritability estimated by the regression has given a value of 0.74 $\left(b_{\bar{F} P}=-0.1924 ; b_{\bar{F} M}=0.3619 ; b_{\bar{F} \bar{G}}=1.6096\right)$. When the ANOVA was employed, the value was 1.09; the reasons for such a discrepancy can probably be ascribed to the assumptions used in the model.

\section{Discussion}

The present report deals with the variability of the red raylets in Heliconius erato phyllis inhabiting a subtropical area of Brazil (fig. 1). Tables 1 and 2 (see also fig. 4) summarise the distribution of that trait including its mean and standard deviation. Males and females showed no significant differences as was previously reported by Saalfeld and Araújo (1981). Both sexes were therefore pooled in the analysis.

A single significant difference in space was obtained, namely along $\mathrm{km} 2$, $\mathrm{km} 4$ and $\mathrm{km} 7$ (road A-Jan/80). Considering that such populations have small effective sizes (Oliveira and Araújo, in preparation), this difference could be due to the action of random genetic drift. The similarities in the remaining distributions could be explained by a small amount of gene flow between subpopulations, since each place was not separated by distances greater than $2 \mathrm{~km}$ (with two exceptions, including the one just cited). Although $H$. erato is referred to as having low values of dispersal (about $200 \mathrm{~m}$ for $H$. erato hydara-Turner, $1971 ; 500 \mathrm{~m}$ for $H$. erato petiveranaBenson, 1981), our data indicate that some individuals can fly distances far greater than $1 \mathrm{~km}$ (from 136 butterflies recaptured-this study-3 per cent had travelled distances varying from 2 to $5 \mathrm{~km}$ ).

Temporal differences are more difficult to explain since no cyclic tendencies were observed. There are some indications, however, that the means for the cold season (July and October in the present study) are slightly lower than those for the hot season (January, February and April). We are not able, at present, to infer any direct action of the environment on the raylets distributions. As shown in fig. 4 the frequency distributions of the red raylets in butterflies collected in the Parque do Turvo were greatly variable: some were unimodal with modes in 3,5 or 6 raylets, others bimodal with modes in 3 and 5 . This last type was the only one found by Saalfeld 

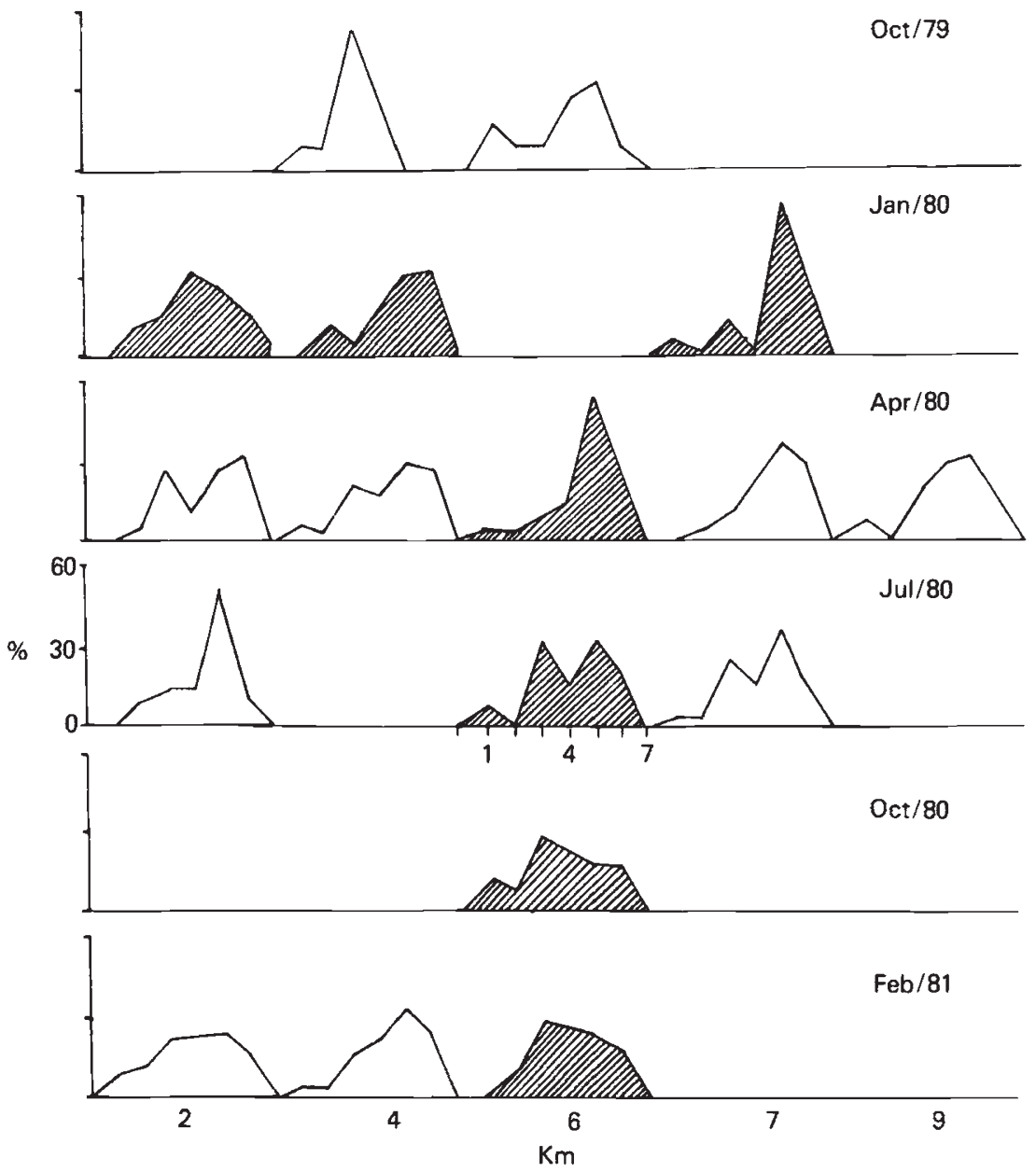

Fig. 4. Frequency polygons of the red raylets in butterflies from Road A. Each row represents a month of the year and each column the same locality in different months. Hatched distributions showed significant differences (see text).

and Araújo (1981) in Itapoã, a place near Porto Alegre (State of Rio Grande do Sul). It is interesting to note that Itapoã is an environment where seasonality is most pronounced, which brings about a sharp decrease in population size in winter, sometimes with extinction. In the Parque do Turvo, on the other hand, the populations remain over the year despite some fluctuations (the smaller size being in October). Additionally, if one considers the diversity in vegetation including host plants (5 species of Passiflora can be found in Turvo, while only 3 are present in Itapoã), as well as the food sources for the adults, the populations living at Itapoã could be considered marginal and those from Turvo as central ones.

The examination of data in table 3 and fig. 3 indicates that the genetic control of the red raylets is not a simple one. As formerly stated an increase in the number of raylets in one parent is followed by a corresponding 
increase in the proportion of the offspring with high number of raylets. This fact, together with the similarity between the means of parents and offspring suggest the action of more than one locus with additive effects. We tried to fit the data to models of two and three loci without success. It would be interesting indeed to test if phenotypes 1 or $6 / 7$ raylets are the corresponding homozygotes for a polygenic system. A suggestion that this could be true comes from the nonsignificant results obtained in the analysis of variance for crosses IV and V (reciprocals). In any case, we believe that our findings do not conflict with those from Sheppard et al., (in press) in which a single gene is proposed for the presence/absence of raylets.

The estimates of heritability by the methods of regression and analysis of variance are not in perfect agreement. The former, using weighted average of regression coefficients gave a value of 0.74 ; perhaps a more realistic estimate could be obtained if all possible combinations between male and female were used, since we got a great variability in the coefficients of regression, from negative to above one.

The value obtained by the analysis of variance was $1 \cdot 09$, which is certainly an overestimate. This can be caused by some simplifying assumptions employed in the model, such as the absence of non-heritable components of the variation within and between, as well as that due to common environment of parents-offspring. It is difficult to quantify such components but in the present study they are probably different from zero, since some males used in the crosses came from the wild and/or by the fact that the offspring has not been reared in standardised conditions (temperature, humidity). This same trend was reported by McWhirter (1969) when he estimated the heritability of spot-number in Maniola jurtina.

Acknowledgements. Thanks are due to the Secretaria da Agricultura do Estado do Rio Grande do Sul, by the facilities allowing us to work in the Parque do Turvo. We also express our gratitude to Campanha de Aperfeiçoamento do Pessoal de Ensino Superior (CAPES); Fundação de Amparo à Pesquisa do Estado do Rio Grande do Sul (FAPERGS); V Câmara (UFRGS) and Conselho Nacional de Desenvolvimento Científico e Tecnológico (CNPq) for the financial support.

\section{REFERENCES}

Beiguelman, B. 1977. Dinâmica dos genes nas familias e nas populações, vol. 2. Ed. da Universidade de São Paulo.

BENSON, W. W. 1981. Alternative models for infrageneric diversification in the humid tropics: tests with Passion Vine butterflies. In Prance, G. (ed.) Biological Diversification in the Tropics, Columbia Univ. Press, pp. 608-644.

BRAKEFIELD, P. M. 1979. Spot-number in Maniola jurtina-variation between generations and selection in marginal populations. Heredity, 42, 259-266.

BRAKEFIELD, P. M. 1982a. Ecological studies on the butterfly Maniola jurtina in Britain. I. Adult behaviour, microdistribution and dispersal. J. An. Ecol, 51, 713-726.

BRAKEFIELD, P. M. 1982b. Ecological studies on the butterfly Maniola jurtina in Britain. II. Population dynamics: the present position. J. An. Ecol., 51, 727-738.

BROWN, K. JR. 1981. The biology of Heliconius and related genera. Ann. Rev. Entomol, 26, 427-456.

BURIOL, G. A., ESTAFANEL, V., FERREIRA, M., SACCOL, A. V., SCHNEIDER, F. M. AND HELDWEIN, A. B. 1979. Cartas mensais e anuais das temperaturas médias, das médias das temperaturas máximas e das médias das temperaturas mínimas do Estado do Rio Grande do Sul. Rev. Centro Ciên. Rurais, 9 (Supl.).

DOWDESWELL, W. H., FISHER, R. A. AND FORD, E. B. 1949. The quantitative study of population in lepidoptera. 2. Maniola jurtina L. Heredity, 3, 67-84. 
EMSLEY, M. G. 1964. The geographical distribution of the color-pattern components of Heliconius erato and Heliconius melpomene with genetical evidence for the systematic relationship between the two species. Zoologica, 49, 245-286.

FORD, E. B. 1975. Ecological Genetics. (4 ${ }^{\text {th }}$ ed.), Chapman and Hall, London.

FRAZER, J. F. D. AND WILLCOX, M. N. A. 1979. Variation in spotting among the close relatives of the butterfly, Maniola jurtina. Heredity, 34, 305-322.

IRGANG, B. E. 1980. A mata do Alto Uruguai no RS. Ciência e Cultura, 32, 323-324.

McWHIRTER, K. G. 1969. Heritability of spot number in scillonian strains of the Meadow Brown butterfly (Maniola jurtina). Heredity, 24, 314-318.

OWEN, D. F. 1971. Tropical Butterflies. Clarendon Press, Oxford.

PLANO DE MANEJO DO PARQUE FLORESTAL ESTADUAL DO TURVO. 1980. Secretaria da Agricultura do Estado do Rio Grande do Sul. 31 p.

SAALFELD. K. AND ARAÚJO, A. M. 1981. Studies on the genetics and ecology of Heliconius erato (Lepid.; Nymph.). I: Demography of a natural population. Rev. Brasil. Biol., 41, 855-860.

SHEPPARD, P. M., TURNER, J. R. G., BROWN, K. S., JR, BENSON, W. W. AND SINGER, M. C. (in press). Genetics and the evolution of Müllerian mimicry in Heliconius butterflies. Philos. Trans. R. Soc. London Ser. B.

TURNER, J. R. G. 1971. Experiments on the demography of tropical butterflies. II. Longevity and home range behaviour in Heliconius erato. Biotropica, 3, 21-31.

TURNER, J. R. G. 1981. Adaptation and evolution in Heliconius: a defense of Neodarwinism. Ann. Rev. Ecol. Syst., 12, 99-121. 